\title{
Quantitative risks and logistic processes in housing and communal services
}

\author{
Victoria Borkovskaya ${ }^{1}$, Evgeniy Degaev ${ }^{2, *}$, Vladimir Rimshin ${ }^{2}$, and Igor Shubin ${ }^{3}$ \\ ${ }^{1}$ Plekhanov Russian University of Economics, Stremyanny Lane, 36, 117997, Moscow, Russia \\ ${ }^{2}$ Moscow State University of Civil Engineering, Yaroslavskoe shosse, 26, 129337, Moscow, Russia \\ ${ }^{3}$ Research Institute of Building Physics, Lokomotivny pr., 21, 127238, Moscow, Russia
}

\begin{abstract}
Improving the quality of housing and communal services for the population is impossible without taking into account the risks, improving the management system and servicing the housing stock. Effective management in the housing stock is possible by using a logistics approach, creating professional competition, creating a real system of economic motivation for managing organizations to reduce quantitative risks and improve the quality of services provided.
\end{abstract}

\section{Introduction}

Housing and communal services are an important component of the service sector, which is included in the territorial production and non-production infrastructure. Housing and communal services are of great importance for the life of the population, because the quality of housing, comfortable environment, organized public transport and other services directly create comfort in localities, affect the health and social climate, and determine one of the components of the quality of life.

For any country, it is necessary to develop the sphere of housing and communal services, since it is the main measure of social development in General. The positive impact on the level and quality of life of the population (households) provokes an increase in the efficiency of social reproduction of capital (including human capital), which is determined by the efficiency of housing and communal services.

As a branch of the national economy (type of economic activity) housing and communal services has the following features:

1. Combines both production and non-production functions related to the production of material goods and the provision of services.

2. It has a special social significance, which causes the need for state regulation and control by public authorities and end users.

3. Includes both commercial (profit-oriented) and non-profit organizations.

4. This industry is represented by both natural (technological) monopolies (energy transportation, water supply and sanitation) and industries where competition is possible and necessary (production of goods and services).

\footnotetext{
*Corresponding author: degaev@inbox.ru, Borkovskaya.VG@rea.ru
} 
5. Variety of organizational and legal status of business structures (with or without legal entity formation) and forms of ownership.

6. Includes large and small businesses.

7. Dispersal of service centers according to the settlement system, which determines the special role of local (municipal) authorities and self-government.

8. High role of environmental and sanitary-epidemiological control.

9. The need to ensure a guaranteed minimum of housing services, regardless of the solvency of the population.

10. Diversity of consumers (citizens, their associations, enterprises and business structures, budget organizations).

In order to raise the level and quality of life of the population, improve their living conditions and cultural environment, it is necessary to increase the requirements for housing and communal services, to engage in its development and improvement. Service in housing and communal services is to provide the population with municipal resources without interruption, and not by selling services. Therefore, logistics in housing and communal services requires constant improvement and introduction of modern methods and technologies [1-5].

\section{Materials and Methods}

To determine the logistics flows and risks in the housing and utilities sector, consider the activities of the management company (CC).

The main activity of the management company is the management of residential and non-residential funds. The main goal of the activity is to implement measures to implement the tasks of reliable, safe and high-quality provision of housing, communal and other services on the territory of the served area, including management of apartment buildings, landscaping and maintenance of municipal and engineering systems, as well as capital repairs. Maintaining a good sanitary condition of entrances, basements, attics and other auxiliary premises.

For effective management of an apartment building (MCD), the criminal code enters into contract agreements with organizations to perform a set of works on the proper maintenance and operation of residential buildings in accordance with management agreements, regulations:

- for current repairs, major repairs, operation and maintenance of the housing stock;

- to perform a set of works on the organization of cleaning and sanitary maintenance of common areas of apartment buildings;

- for repair and construction work to eliminate accidents of engineering equipment systems of residential buildings;

- other contracts for maintenance of Elevator facilities, gas facilities; for the supply of cold and hot water supply, water disposal (sewage disposal), Central heating, power supply of public areas (attics, basements, stairwells).

In General, the management company provides a full range of services for the operation and maintenance of apartment buildings:

1. The management of housing stock.

2. Carrying out major repairs.

3. Maintenance and maintenance of buildings, structures, and territories.

4. Repair and construction maintenance of objects.

5. Round-the-clock operation of the dispatch service.

6. Sanitary maintenance of objects (maintenance and cleaning of the local area, common areas, garbage chutes, garbage removal).

7. Maintenance of individual heat points (ITP) and Central heat point (CTP). 
8. Acceptance and commissioning of residential buildings from construction organizations.

9. Maintenance and operation of engineering systems and equipment.

10. Conclusion of contracts with resource-supplying companies and other related organizations that ensure the life of the district.

The main tasks of the criminal code are:

- creating and maintaining comfortable and safe living conditions for people;

- implementation of a set of measures that increase the stability and reliability of public life support systems;

- improving the quality of public services and implementing resource-saving technologies to reduce costs;

- preparing for the winter of the housing stock and ensuring reliable operation of all systems of engineering support of the housing stock in the autumn-winter period.

The main logistics functions of the $\mathrm{CC}$ are:

- formation of economic relations for the supply of goods or services, their development, adjustment and rationalization;

- determining the volume and direction of material flows;

- preparation of forecast estimates of demand for transportation;

- determining the sequence of product promotion through storage locations;

- inventory management in the field of circulation;

- transportation, as well as all necessary operations along the route of goods to their destinations;

- performing operations immediately preceding and completing the shipment;

- management of all warehouse operations [2-4].

\section{Results and Discussion}

Let's consider the main logistics solutions for the implementation of production activities of the criminal code. Let's consider the principles of forming economic relations for the supply of goods or services, their development, adjustment and rationalization.

\subsection{Selecting a supplier}

When you select a supplier, you initially search for potential suppliers and then compare them. Identify the main and additional features by which suppliers are evaluated.

Main characteristics of suppliers: price of delivered products; quality of delivered products; delivery time.

Additional characteristics: the results of already concluded contracts, i.e. supplier obligations about the delivery time, assortment, completeness, quantity and quality of supplied products; flexible pricing policy, that is, a system of cumulative discounts on the volumes of purchased products, special price lists for regular customers; suppliers ability to deliver products on their own; the opportunity of obtaining goods without advance payment or with deferred payment; the timing of current and emergency orders; organization of quality management at the supplier; prospects of the supplier - the pace of its development, expansion of the range.

Let's look at an example of selecting a window block supplier for major repairs of public spaces.

We recommend using the prioritization method for evaluating suppliers: the actual evaluation of suppliers is based on the results of their work. For this purpose, the most important evaluation criteria are selected. To solve this problem, a table is compiled (table 
1), which indicates the main and additional features of the proposed suppliers in the amount of at least 10 pieces [6-8].

Table 1. Main and additional features of prospective suppliers.

\begin{tabular}{|c|c|c|c|}
\hline $\begin{array}{l}\text { Description } \\
\text { of indicators }\end{array}$ & Supplier \#1 & Supplier \#2 & Supplier \#3 \\
\hline Unit price & 1500 rubles. & 1530 rubles. & 1490 rubles. \\
\hline $\begin{array}{l}\text { The cost of } \\
\text { the entire }\end{array}$ & 15,000 rubles. & 15300 rubles. & 14900 rubles. \\
\hline $\begin{array}{c}\text { Term of } \\
\text { execution }\end{array}$ & $\begin{array}{c}\text { within } 3 \text { business } \\
\text { days after } \\
\text { payment } \\
\end{array}$ & $\begin{array}{l}\text { within } 2 \text { business days } \\
\text { after payment }\end{array}$ & $\begin{array}{c}\text { within } 4 \text { business days } \\
\text { after payment }\end{array}$ \\
\hline $\begin{array}{l}\text { Payment } \\
\text { term }\end{array}$ & $\begin{array}{l}100 \% \text { prepayment } \\
\text { within } 5 \text { banking } \\
\text { days from the date } \\
\text { of signing the } \\
\text { agreement }\end{array}$ & $100 \%$ prepayment & $\begin{array}{c}100 \% \text { prepayment within } \\
5 \text { banking days from the } \\
\text { date of signing the } \\
\text { agreement }\end{array}$ \\
\hline $\begin{array}{l}\text { Responsibilit } \\
\text { y of parties }\end{array}$ & $\begin{array}{l}\text { Information not } \\
\text { provided }\end{array}$ & $\begin{array}{l}\text { In case of non- } \\
\text { compliance with the } \\
\text { agreed delivery date, } \\
\text { the supplier pays the } \\
\text { buyer a penalty of } \\
0.5 \% \text { for each day of } \\
\text { delay of the total } \\
\text { amount of the } \\
\text { undelivered goods, and } \\
\text { the total amount of the } \\
\text { final penalty should not } \\
\text { exceed } 5 \% \text { of the total } \\
\text { amount of the } \\
\text { undelivered goods }\end{array}$ & $\begin{array}{l}\text { In case of non- } \\
\text { compliance with the } \\
\text { agreed delivery date, the } \\
\text { supplier pays the buyer a } \\
\text { penalty of } 0.2 \% \text { for each } \\
\text { day of delay of the total } \\
\text { amount of the } \\
\text { undelivered goods, and } \\
\text { the total amount of the } \\
\text { final penalty should not } \\
\text { exceed } 15 \% \text { of the total } \\
\text { amount of the } \\
\text { undelivered goods }\end{array}$ \\
\hline Delivery & $\begin{array}{l}\text { Free delivery in } \\
\text { the city }\end{array}$ & Free delivery in the city & $\begin{array}{c}\text { Pickup from the } \\
\text { supplier's warehouse }\end{array}$ \\
\hline $\begin{array}{c}\text { Other } \\
\text { condition }\end{array}$ & $\begin{array}{l}\text { The supplier gives } \\
\text { a guarantee of } 3 \\
\text { months from the } \\
\text { date of payment, }\end{array}$ & $\begin{array}{l}\text { Supplier replace } \\
\text { defective valves within } \\
\text { one month from the } \\
\text { date of payment }\end{array}$ & $\begin{array}{c}\text { Supplier replace } \\
\text { defective valves within } \\
60 \text { days from the date of } \\
\text { payment, provided a } \\
\text { quality certificate }\end{array}$ \\
\hline Location & city of Moscow & city of Moscow & city of Moscow \\
\hline $\begin{array}{c}\text { Note / } \\
\text { comment }\end{array}$ & $\begin{array}{l}\text { The price is } \\
\text { average, the } \\
\text { Warranty period } \\
\text { is } 3 \text { months - the } \\
\text { longest. } \\
\text { Free shipping is } \\
\text { provided. No } \\
\text { quality certificate } \\
\text { was provided. }\end{array}$ & $\begin{array}{c}\text { The price is the } \\
\text { highest, free shipping is } \\
\text { Provided, the shortest } \\
\text { warranty period, and no } \\
\text { quality certificate is } \\
\text { provided. }\end{array}$ & $\begin{array}{c}\text { The price is the lowest, } \\
\text { but the CC must take the } \\
\text { goods out of the } \\
\text { warehouse itself, which } \\
\text { will lead to additional } \\
\text { costs for the partnership. } \\
\text { The warranty period is } \\
\text { shorter than that of } \\
\text { supplier \#1. } \\
\text { Quality certificate } \\
\text { provided. }\end{array}$ \\
\hline
\end{tabular}


Next, the most important evaluation criteria for a particular organization are selected, and the supplier is finally selected.

In this case, it is recommended that the vendor No. 3. The purchase price is lower than that of other suppliers and the offer has a number of favorable conditions for the management company: confirmation of quality and the longest warranty period, which reduces the risks of receiving low-quality products and makes it possible to exchange them under the warranty, as well as in case of non-compliance with the agreed delivery date, the supplier pays the buyer a penalty of $0.2 \%$ for each day of delay from the total amount of undelivered goods.

\subsection{Placement of materials in the warehouse}

Determining an acceptable option for placing materials is to determine the optimal storage locations for products in the warehouse.

During major repairs, the most necessary materials make up only a small part of the range, and they must be placed along the so-called "hot" lines or zones. Materials that are not used for major repairs are relegated to the "background" and placed along the "cold" lines (zones) (figure 1). Large-sized materials and tools are also located along the " hot " lines, since their movement is associated with significant difficulties.

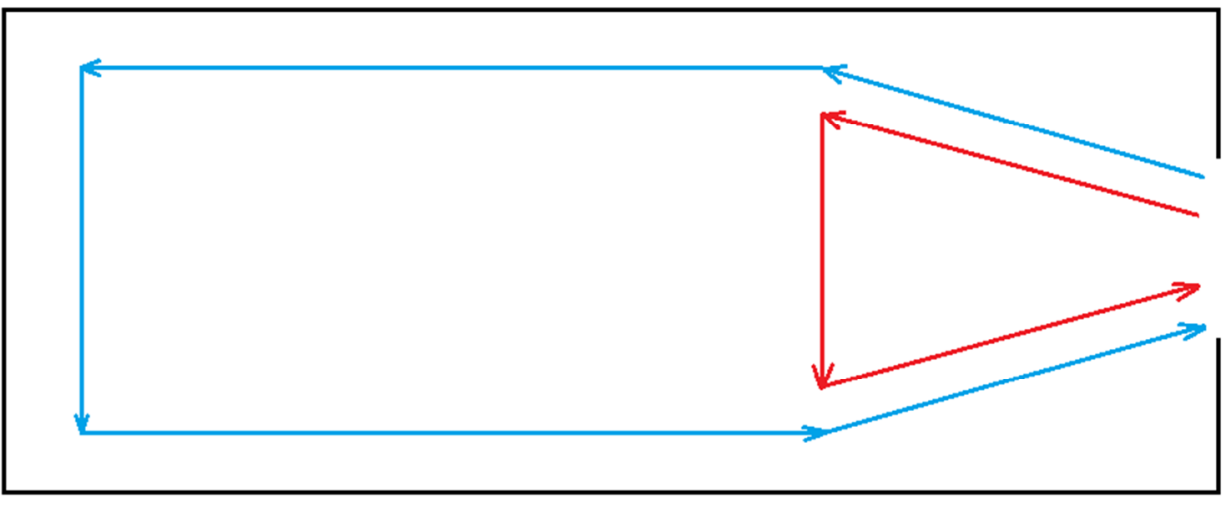

Fig. 1. Separation of flows in the warehouse.

Let's consider an example of placing materials in a warehouse during major repairs of the facade. Work will be carried out: plastering the facade-OF, replacement of window blocks (with the consent of the tenant) - OK.

Let's assume that the cargo arrives and is released in whole cargo packages, is stored in racks on pallets in packaged form, and all operations with it are fully mechanized. In total, 140 cargo packages were received during the previous period, and the same number was released.

Table 2. The range of the product and its quantity in stock.

\begin{tabular}{|c|c|}
\hline Product (name of assortment item) & Number of cargo packages \\
\hline OF & 70 \\
\hline OK & 40 \\
\hline
\end{tabular}

It is necessary to select a significant (in terms of the number of intra-warehouse movements) assortment of the warehouse and place it in the " hot " zone. The length of one 
storage location is assumed to be $1 \mathrm{~m}$. Then the length of the entire storage area is $2 \mathrm{~m}$.in this case, the value of each cell is multiplied by twice the distance from the storage location to the acceptance and release zone. The resulting values are then summarized by row and column.

Table 3. Distribution by random law.

\begin{tabular}{|c|c|c|c|}
\hline $\begin{array}{c}\text { Product (name of } \\
\text { the assortment } \\
\text { item) }\end{array}$ & $\begin{array}{c}\text { Number of cargo } \\
\text { packages }\end{array}$ & $\begin{array}{c}\text { The distance to the } \\
\text { boundary of acceptance } \\
\text { and release }\end{array}$ & Transportation work \\
\hline OK & 40 & 1 & 80 \\
\hline OF & 70 & 2 & 280 \\
\hline \multicolumn{2}{|r|}{} & Total amount: 360 \\
\hline
\end{tabular}

After determining the transport work for a random location of the product, you need to move the most requested products closer to the exit and determine the reduction in transport work.

Table 4. Distribution of goods based on the results of reduced transport work.

\begin{tabular}{|c|c|c|c|}
\hline $\begin{array}{c}\text { Product (name of } \\
\text { the assortment } \\
\text { item) }\end{array}$ & $\begin{array}{c}\text { Number of cargo } \\
\text { packages }\end{array}$ & $\begin{array}{c}\text { The distance to the } \\
\text { boundary of acceptance } \\
\text { and release }\end{array}$ & Transportation work \\
\hline OF & 70 & 1 & 140 \\
\hline OK & 40 & 2 & 160 \\
\hline \multicolumn{2}{|r}{} & Total amount: 300 \\
\cline { 2 - 3 }
\end{tabular}

Transport work decreased by $20 \%$, thus reducing the time of loading and sending goods.

\section{Conclusions}

When analyzing the activities of housing and communal services quantifying the risks can appear under uncertainty in market prices for fuel, non-payments of consumers, decreased liquidity and lack of funds to make payments to counterparties and in poor condition housing, poor quality materials and are not optimized logistics processes [8-38].

\section{References}

1. V.G. Borkovskaya, E.N. Degaev, I. Burkova, MATEC Web of Conferences 193, 05027 (2018). DOI: https://doi.org/10.1051/matecconf/201819305027.

2. E.N. Degaev, A. Suvorova, A. Suhova, IOP Conf. Ser.: Mater. Sci. Eng. 365, 032019 (2018). DOI: https://doi.org/10.1088/1757-899X/365/3/032019.

3. E.N. Degaev, V. Razvalyaeva, S. Sabenina, IOP Conf. Ser.: Mater. Sci. Eng. 365, 062037 (2018). DOI: https://doi.org/10.1088/1757-899X/365/6/062037.

4. E. Degaev, V. Rimshin, J. Phys.: Conf. Ser. 1425, 012153 (2019). DOI: https://doi.org/10.1088/1742-6596/1425/1/012153.

5. E. Degaev, R. Barkhi, J. Phys.: Conf. Ser. 1425, 012066 (2019). DOI: https://doi.org/10.1088/1742-6596/1425/1/012066.

6. E. Degaev. IOP Conf. Ser.: Mater. Sci. Eng. 661, 012109 (2019). DOI: https://doi.org/10.1088/1757-899X/661/1/012109. 
7. V.G. Borkovskaya, Materials Science and Mechanical Engineering. 2, 287-290 (2013). DOI: 10.4028/www.scientific.net/AMM.467.287

8. V.G. Borkovskaya Advanced Materials Research 860-863, 3009-3012 (2013). DOI: 10.4028/www.scientific.net/AMR.860-863.3009

9. V.G. Borkovskaya Applied Mechanics and Materials 475-476, 1703-1706 (2013). DOI: 10.4028/www.scientific.net/AMM.475-476.1703

10. V. Borkovskaya, D. Passmore, MATEC Web of Conf. 193, 05027 (2018). DOI: https://doi.org/10.1051/matecconf/201819305026

11. V.G, Borkovskaya, D. Passmore, Smart Technologies and Innovations in Design for Control of Technological Processes and Objects: Economy and Production 24 (2018), DOI:10.1007/978-3-030-15577-3_24

12. V.G. Borkovskaya, MATEC Web of Conferences 251, 06025 (2018). DOI: https://doi.org/10.1051/matecconf/201825106025

13. V. Rimshin, B. Labudin, V. Morozov, A. Kazarian, V. Kazaryan, EMMFT-2019, 983, 867-876 (2019)

14. E. Kuzina. V. Rimshin, Advances in Intelligent Systems and Computing 983, 911-919 (2019)

15. A. Varlamov, V. Rimshin, S. Tverskoi, E3S Web of Conferences 91, 02046 (2019)

16. V.O. Evseev, V.G. Borkovskaya, R. Barkhi, IOP Conf. Series: Journal of Physics: Conf. Series 1425, 012175 (2020). doi:10.1088/1742-6596/1425/1/012175

17. D. Passmore, V.G. Borkovskaya, IOP Conf. Series: Journal of Physics: Conf. Series 1425, 012166 (2020). doi:10.1088/1742-6596/1425/1/012166

18. E. Kuzina, V. Rimshin, V. Kurbatov, IOP Conference Series: Materials Science and Engineering 463(4), 042009 (2018)

19. A.A. Varlamov, V.I. Rimshin, S.Y. Tverskoi, IOP Conference Series: Materials Science and Engineering 463(2), 022028 (2018)

20. A.A. Varlamov, V.I. Rimshin, S.Y. Tverskoi, IOP Conference Series: Materials Science and Engineering 463(2), 022029 (2018)

21. N.I. Karpenko, V.A. Eryshev, V.I. Rimshin, IOP Conference Series: Materials Science and Engineering 463(3), 032024 (2018)

22. E. Kuzina, V. Rimshin, Advances in Intelligent Systems and Computing 692, 410-416 (2018)

23. E. Kuzina, A. Cherkas, V. Rimshin, IOP Conference Series: Materials Science and Engineering 365(3), 032053 (2018)

24. V.G. Borkovskaya, Yu. Korytova, IOP Conference Series: Materials Science and Engineering 661(1) (2019)

25. A.A. Varlamov, V.I. Rimshin, S.Y. Tverskoi, IFAC-PapersOnLine 51(30), 808-811 (2018) 